\title{
Organonickel(II) Complexes with Anionic Tridentate 1,3-Bis(azolylmethyl)phenyl Ligands. Synthesis, Structural Characterization and Catalytic Behavior
}

\author{
John Hurtado, ${ }^{a}$ Andrés Ibañez, ${ }^{b}$ René Rojas, ${ }^{a}$ Mauricio Valderrama ${ }^{*, a}$ and Roland Fröhlich \\ ${ }^{a}$ Departamento de Química Inorgánica, Facultad de Química, \\ Pontificia Universidad Católica de Chile, Casilla 306, 6094411 Santiago, Chile \\ ${ }^{b}$ Centro para la Investigación Interdisciplinaria Avanzada en Ciencia de los Materiales (CIMAT), \\ Santiago, Chile \\ 'Organisch Chemisches Institut der Universität Münster, Corrensstrasse 40, \\ 48149 Münster, Germany
}

\begin{abstract}
A reação de 2-bromo-1,3-bis(bromometil)benzeno com 3,5-dimetilpirazol e 1H-indazol produz os ligantes tridentados 2-bromo-1,3-bis(3,5-dimetilpirazol-1-ilmetil)benzeno (1) e 2-bromo-1,3bis(indazol-2-ilmetil)benzeno (2). Estes compostos reagem com $\left[\mathrm{Ni}(\mathrm{cod})_{2}\right]$ em tetraidrofurano (thf) para formar os complexos de adição oxidativa [ $\mathrm{NiBr}\{1,3$-bis(azolilmetil)fenil- $N, C, N\}]$, azol = 3,5-dimetilpirazol (3) e indazol (4), os quais foram isolados em bons rendimentos como sólidos amarelos estáveis e caracterizados por meio de análise elementar, espectroscopia de absorção no infravermelho com transformada de Fourier (FTIR), espectrometria de massa e ressonância magnética nuclear (NMR). Adicionalmente, as estruturas moleculares de $\mathbf{2}$ e $\mathbf{4}$ foram determinadas por difratometria de raios $\mathrm{X}$ de monocristal. O complexo 4 foi testado como catalisador na reação de polimerização de etileno.
\end{abstract}

The reaction of 2-bromo-1,3-bis(bromomethyl)benzene with 3,5-dimethylpyrazole and $1 \mathrm{H}$-indazole yields the tridentate ligands 2-bromo-1,3-bis(3,5-dimethylpirazol-1-ylmethyl)benzene (1) and 2-bromo-1,3-bis(indazol-2-ylmethyl)benzene (2). These compounds react with $\left[\mathrm{Ni}(\mathrm{cod})_{2}\right]$ in tetrahydrofuran (thf) to form the oxidative addition complexes [ $\mathrm{NiBr}$ \{1,3-bis(azolylmethyl)phenyl$N, C, N\}$ ], azol = 3,5-dimethylpyrazol (3), indazol (4), which were isolated in good yields as stable yellow solids and characterized by elemental analysis, Fourier-transform infrared spectroscopy (FTIR), mass spectroscopy and nuclear magnetic resonance (NMR). In addition, the molecular structures of $\mathbf{2}$ and $\mathbf{4}$ were determined by single-crystal X-ray diffraction analysis. Complex $\mathbf{4}$ was tested as a catalyst in ethylene polymerization reaction.

Keywords: nickel, tridentate ligands, cyclometalated complexes, catalytic activity

\section{Introduction}

The synthesis of transition metal complexes having anionic tridentate ligands has received much attention due to their potential applications in homogeneous catalysis. ${ }^{1-8}$ These complexes consist of a metal center bonded to an anionic tridentate ligand with the general formula $\left\{2,6-\left(\mathrm{ECH}_{2}\right)_{2} \mathrm{C}_{6} \mathrm{H}_{3}\right\}^{-}$, where $\mathrm{E}$ is a neutral two-electron donor (N, P, O, S). These compounds are very stable due to the formation of two five-membered metallocycles that provide additional stabilization of the carbon-metal

*e-mail: jmvalder@puc.cl bond. Although the most widely studied complexes are derivatives of the group 10 metals, Ni, Pt and Pd, containing $\mathrm{N}$ or $\mathrm{P}$ as donor atoms, ${ }^{1}$ a limited number of nickel complexes containing NCN pincer ligands have been reported. ${ }^{9-12}$ These nickel pincer complexes are used as catalysts in $\mathrm{C}-\mathrm{C}$ coupling reactions involving aryl halide substrates. ${ }^{4,13-15}$ Some examples are shown in Figure 1.

The synthesis of pincer complexes containing more flexible six-membered rings has been explored, in particular those employing pyridine or pyrazole donor groups connected by a spacer atom to the central aryl ring (Figure 2). ${ }^{16-22}$ 

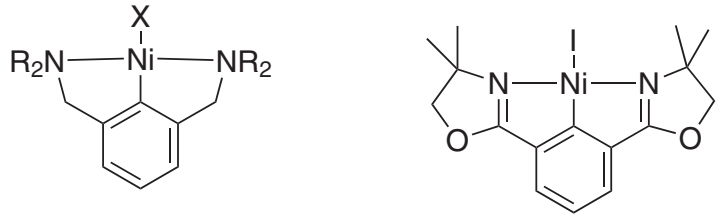

Figure 1. Examples of nickel pincer complexes with five-membered chelate rings. $\mathrm{R}=\mathrm{Me}$, Et or ${ }^{\mathrm{i} r} \mathrm{P} ; \mathrm{X}=\mathrm{Cl}, \mathrm{Br}$ or $\mathrm{O}_{2} \mathrm{CH}$.
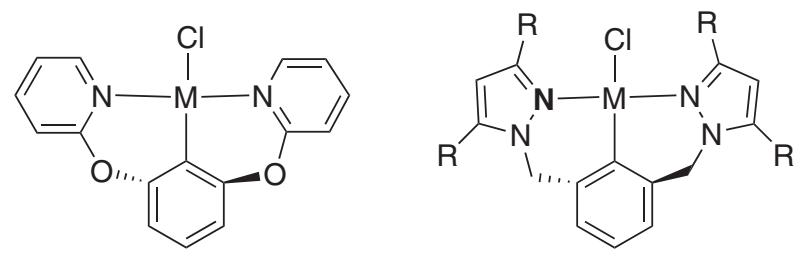

Figure 2. Examples of pincer complexes with six-membered chelate rings, employing pyridine or pyrazole donor groups. $\mathrm{R}=\mathrm{H}$ or Me.

Recently we reported the synthesis and properties of the pincer-type palladium(II) complexes $[\mathrm{PdCl}\{$ bis(azolylmethyl)tolyl- $N, C, N\}]$ showing that they are active in the polymerization of ethylene..$^{23}$ Following our interest in these types of compounds, we report in this paper the synthesis and properties of new nickel(II) bromide complexes bearing bis(azolylmethyl)phenyl type ligands, acting as anionic tridentate $(N, C, N)$ donors. The crystal structure of the ligand 2-bromo-1,3-bis(indazol-2-ylmethyl) benzene and the complex \{bis(indazol-2-ylmethyl)phenyl bromonickel(II), determined by single crystal X-ray diffraction analysis, are also reported. In this work the activity of the above mentioned cyclometalated nickel complex for ethylene polymerization is also described.

\section{Experimental}

\section{General remarks}

The reactions were carried out under an atmosphere of purified nitrogen. All reagent-grade solvents were dried, distilled and stored under a nitrogen atmosphere. The starting compound 2-bromo-1,3-bis(bromomethyl)benzene was synthesized according to literature procedures. ${ }^{24}$ 3,5-Dimethylpyrazole, $1 \mathrm{H}$-indazole and $\left[\mathrm{Ni}(\operatorname{cod})_{2}\right]$ were purchased from Aldrich and used without further purification. Methylaluminoxane (MAO, 10 wt.\% in toluene) was purchased from Witco and used as received. Elemental analyses $(\mathrm{C}, \mathrm{H}, \mathrm{N})$ were carried out using a Fisons EA 1108 CHNS-O microanalyzer. FTIR spectra were recorded throughout the $4000-250 \mathrm{~cm}^{-1}$ region, with samples prepared as $\mathrm{KBr}$ discs on a Bruker Vector-22 spectrophotometer. The NMR spectra were recorded on a Bruker AC-200P and Avance-400 spectrometers and the chemical shifts are reported in ppm relative to $\mathrm{SiMe}_{4}\left({ }^{1} \mathrm{H}\right.$, ${ }^{13} \mathrm{C}$ ). Mass spectra were obtained on a Micromass Quattro LC-Z electrospray mass spectrometer. Melting point was determined using an electrothermal melting point apparatus in open capillary tubes and are uncorrected.

Synthesis of 2-bromo-1,3-bis(3,5-dimethylpyrazol-1ylmethyl)benzene (1)

This compound was prepared by modification of a reported method.$^{16}$ In a Schlenk tube provided with a reflux condenser, 3,5-dimethylpyrazole (1.970 g, $20.5 \mathrm{mmol})$, $\mathrm{KOH}(2.314 \mathrm{~g}, 41.2 \mathrm{mmol})$, tetrabutylammonium bromide (TBAB, $0.212 \mathrm{~g}, 0.63 \mathrm{mmol}$ ) and water $(1 \mathrm{~mL})$ were stirred at room temperature for $25 \mathrm{~min}$. 2-Bromo-1,3-bis(bromomethyl)benzene (3.291 g, 9.6 mmol) and toluene $(25 \mathrm{~mL})$ were then added and the mixture refluxed for $72 \mathrm{~h}$. The resulting mixture was washed with water and the organic layer separated and dried with magnesium sulphate. The filtered solution was evaporated to dryness to give a brown oil (which solidified with time), which was then crystallized from diethyl ether. Yield (1.979 g, 55\%), mp 120-122 ${ }^{\circ} \mathrm{C}$. Anal. Calc. for $\mathrm{C}_{18} \mathrm{H}_{21} \mathrm{BrN}_{4}$ : C, 57.9; N, 15.0; H, 5.7\%. Found: C, 57.6; N, 14.9; H, 5.9\%. FTIR (KBr) $v_{\max } / \mathrm{cm}^{-1}$ : $1555 \mathrm{~s}, 1457 \mathrm{~s}, 1421 \mathrm{~s}, 1385 \mathrm{~s}, 1357 \mathrm{~s}, 1311 \mathrm{~s}, 1025 \mathrm{~s}, 787 \mathrm{~s}$, 769s. ${ }^{1} \mathrm{H}$ NMR $\left(\mathrm{CDCl}_{3}, 22{ }^{\circ} \mathrm{C}\right) \delta(\mathrm{ppm}) 2.13(\mathrm{~s}, 6 \mathrm{H}$, Me5-pyrazol), 2.25 (s, 6H, Me3-pyrazol), 5.9 (s, 2H, H4-pyrazol), 5.30 (s, 4H, $\left.\mathrm{CH}_{2}\right), 6.29$ (d, 2H, J(HH) 7.7 $\mathrm{Hz}, \mathrm{H} 4,6$-aryl) and $7.08(\mathrm{t}, 1 \mathrm{H}, J(\mathrm{HH}) 7.7 \mathrm{~Hz}, \mathrm{H} 5$-aryl). ${ }^{13} \mathrm{C}\left\{{ }^{1} \mathrm{H}\right\} \mathrm{NMR}, \delta$ (ppm) 11 (Me3), $13(\mathrm{Me} 5), 53\left(\mathrm{CH}_{2}\right)$, 106 (C4-pyrazol), 121 (C2-aryl), 126 (C4,6-aryl), 128 (C5-aryl), 137 (C1,3-aryl), 140 (C5-pyrazol) and 148 (C3-pyrazol).

Synthesis of 2-bromo-1,3-bis(indazol-2-ylmethyl)benzene (2)

In a Schlenk tube provided with a reflux condenser, a slurry of indazole (709 mg, $6.0 \mathrm{mmol}), 2$-bromo-1,3bis(bromomethyl)benzene (1.034 g, $3.0 \mathrm{mmol}$ ) and $\mathrm{Et}_{3} \mathrm{~N}$ $(2 \mathrm{~mL})$ in toluene $(50 \mathrm{~mL})$ was heated under reflux for $72 \mathrm{~h}$. The resulting mixture was washed with water $(15 \mathrm{~mL})$ and extracted with chloroform $(2 \times 30 \mathrm{~mL})$. The organic layer was separated and dried with magnesium sulphate. The resulting solution was evaporated to dryness to give a white solid, which was crystallized from dichloromethanediethyl ether. Yield ( $860 \mathrm{mg}, 43 \%$ ). $\mathrm{mp} 165-167^{\circ} \mathrm{C}$. MS-ESI $\left(\mathrm{m} / z, \mathrm{ES}^{+}\right): 417.07[\mathrm{M}]^{+}, 439.05[\mathrm{M}+\mathrm{Na}]^{+}$. Anal. Calc. for $\mathrm{C}_{22} \mathrm{H}_{17} \mathrm{BrN}_{4}$ : C, 63.3; N, 13.4; H, 4.1\%. Found: $\mathrm{C}, 63.3$; $\mathrm{N}, 13.5 ; \mathrm{H}, 4.1 \%$. FTIR $(\mathrm{KBr}) v_{\max } / \mathrm{cm}^{-1}: 1627 \mathrm{w}, 1515 \mathrm{~m}$, 1466w, 1420m, 1383m, 1139m, 1011w, 799m, 783s, 755s, 735s, 636w, 434w. 
Atom numbering for compound $\mathbf{2}$ is as follows:

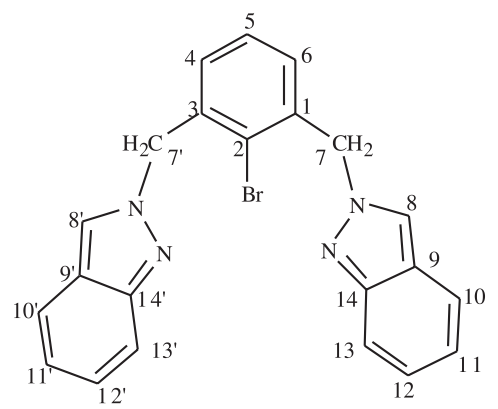

${ }^{1} \mathrm{H}$ NMR $\left(\mathrm{CDCl}_{3}, 22{ }^{\circ} \mathrm{C}\right), \delta(\mathrm{ppm}) 5.74\left(\mathrm{~s}, 4 \mathrm{H}, \mathrm{CH}_{2}\right)$, $6.84(\mathrm{~d}, 2 \mathrm{H}, J(\mathrm{HH}) 7.6 \mathrm{~Hz}, \mathrm{H} 4,6) ; 7.09(\mathrm{t}, 2 \mathrm{H}, J(\mathrm{HH})$ $\left.7.6 \mathrm{~Hz}, \mathrm{H} 11,11^{\prime}\right) ; 7.15(\mathrm{t}, 1 \mathrm{H}, J(\mathrm{HH}) 7.6 \mathrm{~Hz}, \mathrm{H} 5), 7.29$ (t, $\left.2 \mathrm{H}, J(\mathrm{HH}) 7.6 \mathrm{~Hz}, \mathrm{H} 12,12^{\prime}\right), 7.64(\mathrm{~d}, 2 \mathrm{H}, J(\mathrm{HH}) 7.6 \mathrm{~Hz}$, $\left.\mathrm{H} 10,10^{\prime}\right), 7.72\left(\mathrm{~d}, 2 \mathrm{H}, J(\mathrm{HH}) 7.7 \mathrm{~Hz}, \mathrm{H} 13,13^{\prime}\right)$ and 7.95 (s, 2H, H8,8'). ${ }^{13} \mathrm{C}\left\{{ }^{1} \mathrm{H}\right\}$ NMR, $\delta$ (ppm) 57.7 (C7,7'), 117.8 (C13,13'), 120.4 (C10,10'), 122.2 (C11,11'), 122.2 (C1,C2,C3), 123.8 (C8,8'), 126.4 (C12,12'), 128.5 (C5), 129.8 (C4,C6), $136.6\left(\mathrm{C} 9,9^{\prime}\right)$ and $149.4\left(\mathrm{C} 14,4^{\prime}\right)$.

Synthesis of [NiBr\{1,3-bis(azolylmethyl)phenyl-N,C,N\}] [azol = 3,5-dimethylpyrazol (3), indazol (4)]

A solution of the corresponding ligand $(0.38 \mathrm{mmol})$ in thf $(15 \mathrm{~mL})$ was added via syringe to a solution of $\left[\mathrm{Ni}(\operatorname{cod})_{2}\right]$ (cod $=1,5$-cyclooctadiene) $(102 \mathrm{mg}, 0.37 \mathrm{mmol})$ in thf $(10 \mathrm{~mL})$ at $-78^{\circ} \mathrm{C}$. The reaction mixture was slowly warmed to room temperature and then stirred for $3 \mathrm{~h}$. During this time a yellow solid was formed, which was filtered off, washed with thf and pentane, and then dried under vacuum.

\section{Complex 3}

Yield (139 mg, 87\%). MS-ESI ( $\mathrm{m} / \mathrm{z}, \mathrm{ES}+): 351.11$ [M-Br] $]^{+}$. Anal. Calc. for $\mathrm{C}_{18} \mathrm{H}_{21} \mathrm{BrN}_{4} \mathrm{Ni}: \mathrm{C}, 50.0 ; \mathrm{N}, 13.0$; H, 4.9\%. Found: C, 49.0; N, 12.7; H, 4.5\%. FTIR (KBr) $v_{\max } / \mathrm{cm}^{-1}: 1554 \mathrm{~s}, 1466 \mathrm{~s}, 1431 \mathrm{~s}, 1394 \mathrm{~s}, 1354 \mathrm{~m}, 1264 \mathrm{~s}$, 790s, 779s, 733s, 670m. ${ }^{1} \mathrm{H}$ NMR $\left(\mathrm{CDCl}_{3},-20{ }^{\circ} \mathrm{C}\right): \delta$ (ppm) 2.3 (s, 6H, Me5-pyrazol), 2.7 (s, 6H, Me3-pyrazol), 5.8 (s, 2H, H4-pyrazol), 4.9 (d, 2H, $J(\mathrm{HH}) 14.0 \mathrm{~Hz}, \mathrm{CH}_{2}$ ), $6.3\left(\mathrm{~d}, 2 \mathrm{H}, J(\mathrm{HH}) 14.0 \mathrm{~Hz}, \mathrm{CH}_{2}\right)$ and 6.8 (s, H4,5,6-aryl). ${ }^{13} \mathrm{C}\left\{{ }^{1} \mathrm{H}\right\}$ NMR, $\delta$ (ppm) 11.7 (Me3), 17.3 (Me5), 53.8 (CH2), 107.6 (C4-pyrazol), 123.2, 123.4, 123.5 (C-Ni), 138.7, 141.2, 153.6.

\section{Complex 4}

Yield (134 mg, 76\%). MS-ESI ( $\mathrm{m} / \mathrm{z}, \mathrm{ES}+)$ : 395.08 [M-Br] $]^{+}$. Anal. Calc. for $\mathrm{C}_{22} \mathrm{H}_{17} \mathrm{BrN}_{4} \mathrm{Ni}$ : C, 55.5; N, 11.8; $\mathrm{H}, 3.6 \%$. Found: C, 55.0; N, 11.7; H, 3.8\%. FTIR (KBr) $v_{\max } / \mathrm{cm}^{-1}: 1626 \mathrm{~s}, 1519 \mathrm{~m}, 1478 \mathrm{w}, 1438 \mathrm{~m}, 1376 \mathrm{w}, 1294 \mathrm{~m}$, $1159 \mathrm{~m}, 1142 \mathrm{~m}, 787 \mathrm{~m}, 755 \mathrm{~m}, 739 \mathrm{~s}, 639 \mathrm{w} .{ }^{1} \mathrm{H}$ NMR (acetone- $\left.d_{6},-20^{\circ} \mathrm{C}\right) \delta(\mathrm{ppm}) 5.8(\mathrm{~d}, 2 \mathrm{H}, J(\mathrm{HH}) 14.0 \mathrm{~Hz}$, $\left.\mathrm{CH}_{2}\right), 6.6\left(\mathrm{~d}, 2 \mathrm{H}, J(\mathrm{HH}) 14.0 \mathrm{~Hz}, \mathrm{CH}_{2}\right), 6.7(\mathrm{t}, 1 \mathrm{H}, J(\mathrm{HH})$ $7.2 \mathrm{~Hz}, \mathrm{H}$ ), 6.9 (d, 2H, J(HH) $7.2 \mathrm{~Hz}, \mathrm{H} 4,6), 7.1$ (t, 2H, $J(\mathrm{HH}) 7.3 \mathrm{~Hz}, \mathrm{H} 11), 7.3$ (t, 2H, $J(\mathrm{HH}) 7.3 \mathrm{~Hz}, \mathrm{H} 12)$, $7.6(\mathrm{~d}, 2 \mathrm{H}, J(\mathrm{HH}) 8.4 \mathrm{~Hz}, \mathrm{H} 10), 8.6(\mathrm{~s}, 2 \mathrm{H}, \mathrm{H} 3)$ and 8.8 (d, $2 \mathrm{H}, J(\mathrm{HH}) 8.8 \mathrm{~Hz}, \mathrm{H} 13) .{ }^{13} \mathrm{C}\left\{{ }^{1} \mathrm{H}\right\}$ NMR (acetone- $d_{6}$, $\left.22^{\circ} \mathrm{C}\right): \delta(\mathrm{ppm}) 57.7\left(\mathrm{CH}_{2}, \mathrm{C} 7,7^{\prime}\right), 117.8\left(\mathrm{C} 13,13^{\prime}\right), 120.4$ (C10,10'), 122.2 (C11,11'), 122.2 (C1,2,3), 123.8 (C8,8'), 126.4 (C12,12'), 128.5 (C5), 129.8 (C4,6), 136.6 (C9,9') and 149.4 (C14,14').

\section{Crystal structure determination for compounds $\mathbf{2}$ and $\mathbf{4}$}

Crystals of $\mathbf{2}$ suitable for X-ray diffraction analysis were grown by slow diffusion of diethyl ether into a dichloromethane solution. Crystal data were collected with a Nonius KappaCCD diffractometer. The structure was solved using SHELXS-97 and the refinement used SHELXL-97. ${ }^{25}$ Crystals of $\mathbf{4}$ were grown by slow diffusion of diethyl ether into an acetone solution of the complex. Intensity data were collected with a Bruker SMART APEX diffractometer. The structure was solved using XS in SHELXTL by means of direct methods, and completed by Fourier difference synthesis. Refinement until convergence was achieved using XL SHELXTL. ${ }^{26}$ Crystallographic details are listed in Table 1.

\section{Ethylene polymerization assays}

Polymerizations were carried out by charging a $100 \mathrm{~mL}$ Parr stainless steel autoclave (in a glove-box under an inert nitrogen atmosphere) with toluene $(21 \mathrm{~mL})$, the desired amount of cocatalyst (methylaluminoxane, MAO, $10 \mathrm{wt} . \%$ in toluene solution) and complex $4(4.2 \mu \mathrm{mol})$. The autoclave was sealed, brought off the glove-box and connected to a mechanical stirrer, a temperature controller and an ethylene consumption control. The reaction was quenched by the addition of $\mathrm{HCl}$-methanol $(15 \mathrm{~mL}, 20 \% \mathrm{v} / \mathrm{v})$. The nickel complex was not recovered after reaction, because it decomposes upon addition of the HCl-methanol mixture. The polymer was isolated by filtration, washed with acetone and dried overnight at room temperature. The polymers were characterized by infrared spectroscopy (FTIR), gel permeation chromatography (GPC) and differential scanning calorimetry (DSC). GPC analysis was performed on a Polymer Laboratories high temperature GPC system (model PL 220) equipped with a refractive index detector. Samples were run at $150{ }^{\circ} \mathrm{C}$ in spectrophotometric grade 1,2,4-trichlorobenzene (TCB), stabilized with butylated hydroxytoluene, BHT (0.5 g BHT/4L solvent). Molecular weights were calculated by 
Table 1. Crystal data and structure refinement for compounds $\mathbf{2}$ and $\mathbf{4}$

\begin{tabular}{|c|c|c|}
\hline Empirical formula & $\mathrm{C}_{22} \mathrm{H}_{17} \mathrm{BrN}_{4}$ & $\mathrm{C}_{22} \mathrm{H}_{17} \mathrm{BrN}_{4} \mathrm{Ni}$ \\
\hline Formula weight & 417.31 & 476.02 \\
\hline Temperature / K & $232(2)$ & $298(2)$ \\
\hline Wavelength / $\AA$ & 1.54178 & 0.71073 \\
\hline Crystal system & monoclinic & monoclinic \\
\hline Space group & $P 2_{1}$ (No. 4$)$ & $P 2_{1} / \mathrm{n}$ \\
\hline \multicolumn{3}{|l|}{ Unit cell dimensions } \\
\hline$a / \AA$ & $10.1155(2)$ & $12.837(2)$ \\
\hline$b / \AA$ & $5.4997(1)$ & $10.1871(17)$ \\
\hline$c / \AA$ & $16.7954(4)$ & $15.617(3)$ \\
\hline$\beta /^{\circ}$ & $106.993(2)$ & $109.959(3)$ \\
\hline Volume / $\AA^{3}$ & $893.57(3)$ & 1919.6(6) \\
\hline $\mathrm{Z}$ & 2 & 4 \\
\hline Density (calculated) $/ \mathrm{Mg} \mathrm{m}^{-3}$ & 1.551 & 1.647 \\
\hline Absorption coefficient $/ \mathrm{mm}^{-1}$ & 3.421 & 3.107 \\
\hline $\mathrm{F}(000)$ & 424 & 960 \\
\hline Crystal size $/ \mathrm{mm}^{3}$ & $0.30 \times 0.30 \times 0.05$ & $0.15 \times 0.14 \times 0.11$ \\
\hline Theta range / degrees & 4.47 to 68.45 & 1.78 to 27.90 \\
\hline Index ranges & $-11 \leq \mathrm{h} \leq 12,-6 \leq \mathrm{k} \leq 5,-20 \leq 1 \leq 19$ & $-16 \leq \mathrm{h} \leq 16,-12 \leq \mathrm{k} \leq 13,-20 \leq 1 \leq 20$ \\
\hline Reflections collected & 6426 & 15636 \\
\hline Independent reflections & $2220[\mathrm{R}$ (int) $=0.037]$ & $4297[\mathrm{R}(\mathrm{int})=0.0377]$ \\
\hline Completeness to theta / degrees & $95.7 \%(\theta=68.45)$ & $99.9 \%(\theta=26.0)$ \\
\hline Refinement method & \multicolumn{2}{|c|}{ Full-matrix least-squares on $\mathrm{F}^{2}$} \\
\hline Data / restraints / parameters & $2220 / 1 / 244$ & $4297 / 0$ / 253 \\
\hline Goodness-of-fit on $\mathrm{F}^{2}$ & 1.051 & 1.020 \\
\hline Final $R$ indices $[I>2 \operatorname{sigma}(I)]$ & $\mathrm{R}_{1}=0.0308, \mathrm{wR}_{2}=0.0821$ & $\mathrm{R}_{1}=0.0402, \mathrm{wR}_{2}=0.0865$ \\
\hline $\mathrm{R}$ indices (all data) & $\mathrm{R}_{1}=0.0309, \mathrm{wR}_{2}=0.0822$ & $\mathrm{R}_{1}=0.0721, \mathrm{wR}_{2}=0.0976$ \\
\hline Largest diff. peak and hole / e $\AA^{-3}$ & 0.578 and -0.495 & 0.785 and -0.466 \\
\hline
\end{tabular}

using a universal calibration from narrow polystyrene standards in the molecular weight range of 580 to 7.5 million $\mathrm{g} \mathrm{mol}^{-1}$. Mark-Houwink parameters of $\mathrm{a}=0.7$ and $\mathrm{k}=47.7$ were utilized to correct for polyethylene. Polymer melting points ( Tm) were determined by differential scanning calorimetry using a Mettler Toledo DSC 821 Calorimetry System Heating Scan at $10{ }^{\circ} \mathrm{C} \mathrm{min}{ }^{-1}$ from $25^{\circ} \mathrm{C}$ to $200{ }^{\circ} \mathrm{C}$. Reported results are those obtained in the second scan.

\section{Results and Discussion}

The ligand 2-bromo-1,3-bis(3,5-dimethylpirazol-1ylmethyl)benzene (1) was prepared by phase-transfer catalyzed reaction of 2-bromo-1,3-bis(bromomethyl) benzene with 3,5-dimethylpyrazole, modifying a previously reported method. ${ }^{16}$ The ligand 2-bromo-1,3-bis(indazol-2ylmethyl)benzene (2), in its turn, was obtained by reaction of 2-bromo-1,3-bis(bromomethyl)benzene with $1 \mathrm{H}$-indazole in refluxing toluene in the presence of $\mathrm{Et}_{3} \mathrm{~N}$. Interestingly, the reaction with $1 \mathrm{H}$-indazole gives the isomer with the indazolyl groups bonded to the carbon spacer through the $\mathrm{N} 2$ atom because the electron pair located at this nitrogen becomes more reactive than the corresponding one to $\mathrm{N} 1$ (Scheme 1). ${ }^{27}$
2<smiles>c1ccc2[nH]ncc2c1</smiles>

$1 \mathrm{H}$-indazole

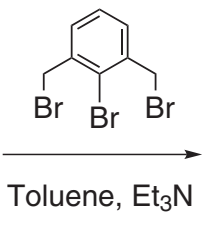

Toluene, $\mathrm{Et}_{3} \mathrm{~N}$
(2)

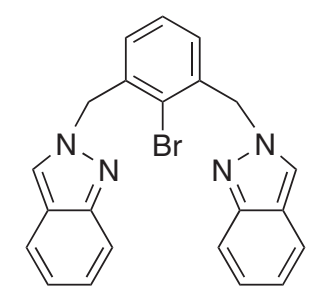

Scheme 1. 
The structures of the ligands were confirmed on the basis of ${ }^{1} \mathrm{H}$ and ${ }^{13} \mathrm{C}$ NMR data and elemental analysis. The ${ }^{1} \mathrm{H}$ and ${ }^{13} \mathrm{C}$ chemical shifts were assigned with the aid of ${ }^{1} \mathrm{H}-{ }^{1} \mathrm{H}$ COSY, DEPT, ${ }^{1} \mathrm{H}^{-13} \mathrm{C}$ HMQC, HMBC and NOESY experiments. Moreover, an X-ray diffraction study was undertaken in order to obtain a complete characterization. For 2, crystals suitable for structure determination were grown by slow diffusion of diethyl ether into a dichloromethane solution of the compound. An ORTEP view of the molecule is presented in Figure 3, and selected bond distances and bond angles are listed in the caption.

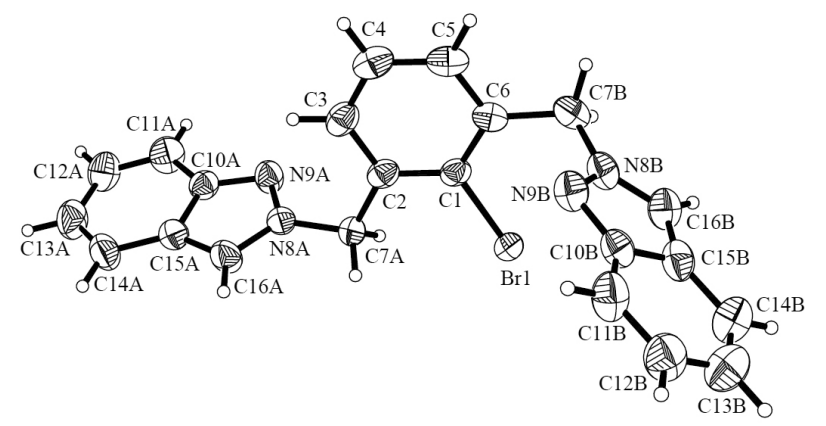

Figure 3. ORTEP plot for compound 2 . The numbering is arbitrary and different from that used in the ${ }^{13} \mathrm{C}$ NMR spectrum. Select bond distances $(\AA)$ and bond angles $\left({ }^{\circ}\right)$ : $\mathrm{N}(8 \mathrm{~A})-\mathrm{N}(9 \mathrm{~A}) 1.349(4), \mathrm{N}(8 \mathrm{~B})-\mathrm{N}(9 \mathrm{~B}) 1.331(4)$, $\mathrm{N}(8 \mathrm{~A})-\mathrm{C}(7 \mathrm{~A}) 1.454(4), \mathrm{N}(8 \mathrm{~B})-\mathrm{C}(7 \mathrm{~B}) 1.452(5), \mathrm{N}(8 \mathrm{~A})-\mathrm{C}(16 \mathrm{~A}) 1.325(5)$, $\mathrm{N}(9 \mathrm{~B})-\mathrm{C}(16 \mathrm{~B}) 1.339(5), \mathrm{C}(1)-\mathrm{Br}(1)$ 1.894(3), N(9A)-N(8A)-C(7A) $118.7(3), \mathrm{N}(9 \mathrm{~B})-\mathrm{N}(8 \mathrm{~B})-\mathrm{C}(7 \mathrm{~B}) 120.4(3), \mathrm{N}(8 \mathrm{~A})-\mathrm{C}(7 \mathrm{~A})-\mathrm{C}(2)$ 114.9(3), $\mathrm{N}(8 \mathrm{~B})-\mathrm{C}(7 \mathrm{~B})-\mathrm{C}(6) 112.6(3), \mathrm{C}(7 \mathrm{~A})-\mathrm{N}(8 \mathrm{~A})-\mathrm{C}(16 \mathrm{~A})$ 126.7(3), $\mathrm{C}(7 \mathrm{~B})-\mathrm{N}(8 \mathrm{~B})-\mathrm{C}(16 \mathrm{~B}) 126.0(3)$.

The benzene and azolyl rings are both planar and the azolyl groups are connected to the methylene spacers through the $\mathrm{N} 2$ atoms. All bonds distances and bonds angles fall within the expected ranges.

Compounds $\mathbf{1}$ and $\mathbf{2}$ react at low temperature $\left(-78^{\circ} \mathrm{C}\right)$ in thf with bis(1,5-cyclooctadiene)nickel $(0),\left[\mathrm{Ni}(\operatorname{cod})_{2}\right]$, to give the oxidative addition complexes of general formula $[\mathrm{Ni}(N, C, N) \mathrm{Br}](\mathbf{3}, \mathbf{4})$. The complexes are isolated as yellow solids, stable in air at room temperature and soluble in acetone, dichloromethane, acetonitrile and chloroform. They were fully characterized by elemental analysis and FTIR, NMR and mass spectroscopies. The NMR spectra of the complexes are consistent with the proposed structure and exhibited the phenyl and azolyl ring resonances, as well as the methylene spacer in the required intensity ratios (see experimental).

In order to confirm the cyclometalated structure of the nickel compounds, a single crystal X-ray diffraction analysis of complex $\mathbf{4}$ was undertaken. A perspective view and the atom labeling of the complex are shown in Figure 4, along with a list of selected bond distances and bond angles. In the complex, the nickel atom is four-coordinate with the tridentate ligand bonded to the metal center through the C(ipso) and the two nitrogen atoms in trans positions; a bromide ligand completes the coordination sphere. The complex has an approximately square-planar coordination involving the $N, C, N, B r$ donor set [deviation of the plane: $\mathrm{Ni}$ $(0.0069 \AA), \mathrm{Br}(0.0046 \AA), \mathrm{C} 14(0.0067 \AA), \mathrm{N} 1(-0.0090 \AA)$ and N2 $(-0.0091 \AA)$. This plane of coordination is twisted $45.3^{\circ}$ out of the plane of the ligand benzene ring.

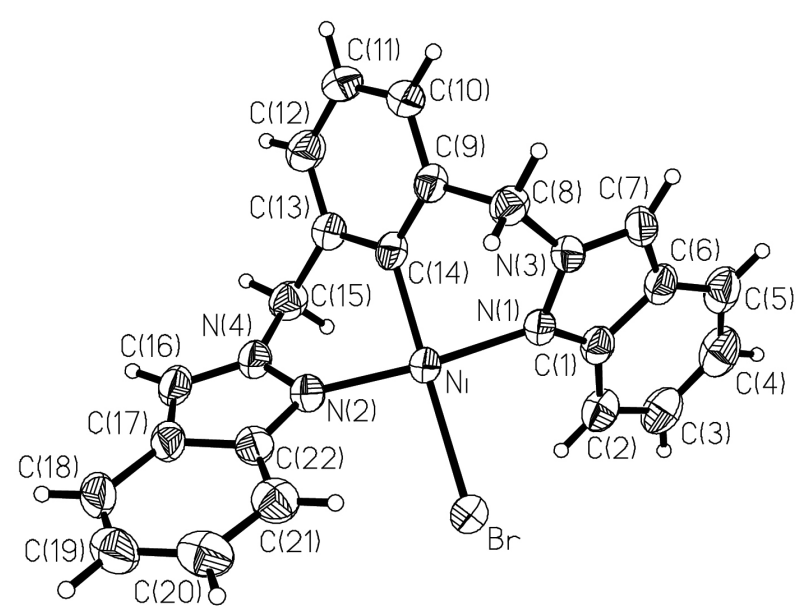

Figure 4. ORTEP representation of complex 4 along with the atom labelling scheme. Selected bond lengths $[\AA]$ and angles $\left[{ }^{\circ}\right]$ : $\mathrm{Ni}(1)-\mathrm{N}(2)$ 1.890(2), Ni(1)-C(14) 1.899(3), Ni(1)-N(1) 1.910(2), Ni(1)- $\mathrm{Br}(1)$ 2.4172(6), N(3)-N(1) 1.349(3), N(4)-N(2) 1.365(3), C(1)-N(1) 1.361(4), $\mathrm{C}(22)-\mathrm{N}(2)$ 1.371(4), N(2)-Ni(1)-C(14) 87.35(12), N(2)-Ni(1)-N(1) 174.65(11), C(14)-Ni(1)-N(1) 87.38(11), N(2)-Ni(1)-Br(1) 92.98(8), $\mathrm{C}(14)-\mathrm{Ni}(1)-\mathrm{Br}(1)$ 179.66(10), N(1)-Ni(1)-Br(1) 92.29(8), N(4)-N(2)$\mathrm{Ni}(1)$ 121.97(19), C(22)-N(2)-Ni(1) 133.7(2), N(3)-N(1)-Ni(1) 121.07(19), C(1)-N(1)-Ni(1) 131.3(2),

The Ni-N [average 1.895(2) ̊], Ni-C [1.899(3) ̊] and $\mathrm{Ni}-\mathrm{Br}[2.4172(6) \AA]$ bond distances are comparable to those found in similar pincer complexes with a bromide ligand in trans position to the bonded $\mathrm{C}$ (aryl) atom, such as $\left[\mathrm{Ni}\left(\mathrm{Me},{ }^{i} \mathrm{Pr}-\mathrm{N}, \mathrm{C}, \mathrm{N}-\mathrm{Me},{ }^{\mathrm{i}} \mathrm{Pr}\right) \mathrm{Br}\right][\mathrm{Ni}-\mathrm{N}$ average 2.000(1) $\AA, \mathrm{Ni}-\mathrm{C}, 1.830(1) \AA$ and $\mathrm{Ni}-\mathrm{Br} 2.437(2) \AA]$ and [Ni(Me, $\left.\left.{ }^{,} \mathrm{Bu}-N, C, N-\mathrm{Me},{ }^{i} \mathrm{Bu}\right) \mathrm{Br}\right][\mathrm{Ni}-\mathrm{N}$ average 2.083(13) $\AA$, $\mathrm{Ni}-\mathrm{C}, 1.825(17) \AA$ and Ni-Br 2.4459(30) $\AA]$ ], ${ }^{11}$ and also to bond distances in some related nickel complexes: $\left[\mathrm{Ni}\left(\mathrm{Me}_{2} \mathrm{~N}, \mathrm{C}, N \mathrm{Ne}_{2}\right)\left(\mathrm{O}_{2} \mathrm{CH}\right)\right][\mathrm{Ni}-\mathrm{N}$ average $1.975(3) \AA$ and $\mathrm{Ni}-\mathrm{C} 1.814(3) \AA]^{12}$ and [Ni(\{2,6-(4,4'-dimethyl-2'oxazolinyl)phenyl- $N, C, N\} \mathrm{I}][\mathrm{Ni}-\mathrm{N}$, average $1.975(3) \AA$ and $\mathrm{Ni}-\mathrm{C} 1.859(4) \AA] .{ }^{9}$

The crystal structure shows that the fused six-membered metallocycles acquired a boat conformation. Interestingly, in this conformation the two hydrogen atoms bonded to the methylene carbons are diastereotopic, giving different signals in the ${ }^{1} \mathrm{H}$ NMR spectra. In fact, in $\mathrm{CD}_{3} \mathrm{CN}$ at $-20{ }^{\circ} \mathrm{C}$ the spectra show two doublets corresponding to the expected AB pattern: complex 3, $\delta 4.9\left(\mathrm{~d},{ }^{2} J(\mathrm{HH})\right.$ $14 \mathrm{~Hz})$ and $6.3\left(\mathrm{~d},{ }^{2} J(\mathrm{HH}) 14 \mathrm{~Hz}\right) \mathrm{ppm}$; complex $4, \delta 5.7$ $\left(\mathrm{d},{ }^{2} J(\mathrm{HH}) 14 \mathrm{~Hz}\right)$ and $6.6\left(\mathrm{~d},{ }^{2} J(\mathrm{HH}) 14 \mathrm{~Hz}\right)$. However, 
variable-temperature experiments reveal the existence of an internal dynamic process. Thus, when the sample was brought to room temperature $\left(25^{\circ} \mathrm{C}\right)$, the spectra showed two broad singlets centered at $\delta 5.0$ and $6.3 \mathrm{ppm}$ (complex 3) and $\delta 5.8$ and 6.6 ppm (complex 4). These results indicate that the environment of the hydrogen atoms changes at higher temperatures due to an inversion of the boat conformation, which is fast on the NMR time scale. Similar results have been described for some related palladium(II) complexes. ${ }^{21,28}$

Treatment of the nickel complexes with silver methanesulfonate in 1:1 molar ratio in acetone or acetone-water solution results in the formation of the non-soluble silver bromide. However, all the attempts to isolate the corresponding cationic solvated complexes were unsuccessful. In all cases white solids, which were very insoluble in organic solvents, were obtained and not characterized further.

In the last few years we have been interested in the synthesis of early and late transition metal complexes containing tridentate pincer ligands, which can activate ethylene to form polyethylene. In recent polymerization studies we found that complexes containing indazolyl groups connected to a central aryl or pyridine ring are more active than the 3,5-pyrazolyl derivatives. For this reason we did not test complex $\mathbf{3}$ in this reaction. ${ }^{23,29,30}$ Thus, the behavior of the nickel complex $\mathbf{4}$ as an initiator for ethylene polymerization under mild conditions was evaluated and compared to the activity of some related palladium complexes bearing the ligands 3,5-bis(azolylmethyl) toluene. ${ }^{23}$ The catalytic activity of the complex in the presence of MAO and the properties of the polymers obtained in these essays are summarized in Table 2.

As far we know, complex $\mathbf{4}$ is the first cyclometalated square-planar nickel complex that is active for the polymerization of ethylene to high molecular weight. As expected, the catalytic activity of $\mathbf{4}$ increases with an increase in the $\mathrm{Al}_{\mathrm{MAO}} / \mathrm{Ni}$ ratio; however, the complex presents lower activity compared with those shown by the related [PdCl\{3,5-bis(indazol-1-ylmethyl)tolyl$N, C, N\}]$ complex under similar conditions $(41 \mathrm{~kg} \mathrm{PE}$ $\left.(\mathrm{mol} \mathrm{Pd})^{-1} \mathrm{bar}^{-1} \mathrm{~h}^{-1} ; \mathrm{Al} / \mathrm{Pd}=2500\right) .{ }^{23}$ Due to the modest activity found for this complex we evaluated the catalytic activity only at $60^{\circ} \mathrm{C}$. We suggest that the polymerization reaction catalyzed by $\mathbf{4}$ occurs by a mechanism similar to those proposed for square-planar cyclopalladate complexes derived from phenylhydrazones ( $C, N, N$-donor) $)^{31}$ where the first step is the replacement of the halide by a methyl group, increasing the electron density of the metal atom, followed by cleavage of the $\mathrm{M}-\mathrm{N}$ bond to generate a vacancy at the metal center (Scheme 3). The lower activity of this complex compared with the similar palladium compound is probably due to the shorter metal-nitrogen bond distances expected for a first row transition metal complex compared with the related second row complex. ${ }^{9}$ Moreover, in the active species the lone pair of the free nitrogen possibly causes an acid-base interaction with $\mathrm{MAO}$, which was previously demonstrated in metal complexes bearing ligands with basic functionalities. ${ }^{32,33}$

GPC, DSC and FTIR techniques were employed to characterize the polymers. GPC analysis shows high molecular weights $\left(\mathrm{M}_{\mathrm{w}}\right)$ with a monomodal molecular

Table 2. Ethylene polymerization reaction with complex $4^{\text {a }}$

\begin{tabular}{lccccccc}
\hline entry & $\mathrm{A} 1 / \mathrm{Ni}$ & Complex $/ \mu \mathrm{mol}$ & $\mathrm{PE}^{\mathrm{b}} / \mathrm{mg}$ & Activity $^{\mathrm{c}}$ & $\mathrm{T}_{\mathrm{m}} /{ }^{\circ} \mathrm{C}$ & $\mathrm{M}_{\mathrm{w}} /\left(\mathrm{g} \mathrm{mol}^{-1}\right)$ & $\mathrm{M}_{\mathrm{w}} / \mathrm{M}_{\mathrm{n}}$ \\
\hline 1 & 1,500 & 4.2 & 25 & 5 & 131 & 200,000 & 2.8 \\
2 & 2,500 & 4.2 & 55 & 23 & 132 & 119,000 & 2.3 \\
\hline
\end{tabular}

aReaction conditions: solvent, toluene $(21 \mathrm{~mL})$; polymerization time, $60 \mathrm{~min}$; stirrer rate, $600 \mathrm{rpm}$; reaction temperature, $60{ }^{\circ} \mathrm{C}$; pressure, $3.5 \mathrm{bar}$; ${ }^{b}$ Polyethylene; ${ }^{c} \mathrm{~kg}$ polymer (mol complex) $)^{-1} \mathrm{bar}^{-1} \mathrm{~h}^{-1}$.
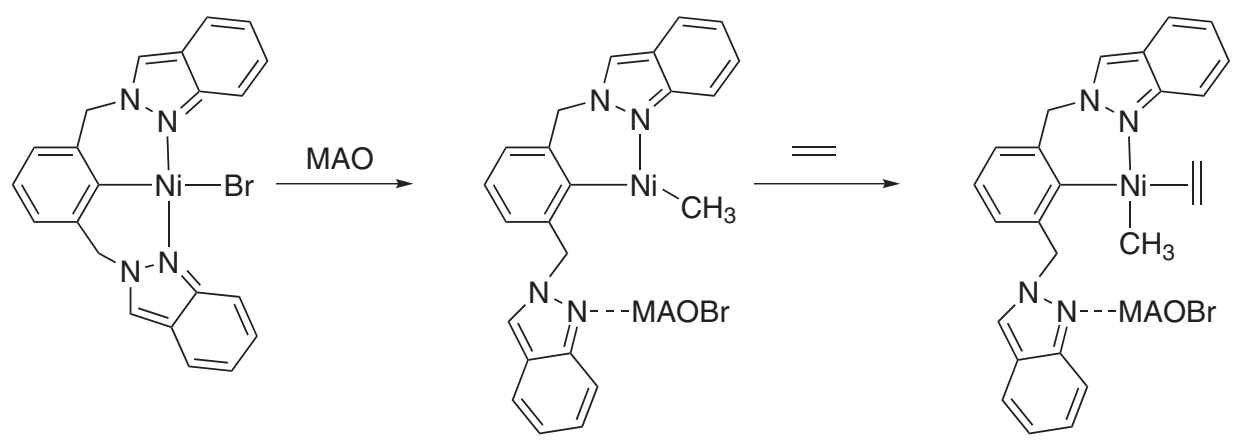

Scheme 2. Proposed polymerization mechanism. 
weight distribution $\left(\mathrm{M}_{\mathrm{w}} / \mathrm{M}_{\mathrm{n}}\right)$ that corresponds to a single-site catalyst. As to the thermal properties, DSC analysis showed melting points in the $131-132{ }^{\circ} \mathrm{C}$ range, indicating the absence of branching in the polymer chain, as confirmed by the FTIR spectra, which show the typical linear polyethylene signals $\left[\mathrm{v}(\mathrm{CH}), 2918\right.$ and $2850 \mathrm{~cm}^{-1}$; $\delta(\mathrm{CH}), 1473$ and $\left.719 \mathrm{~cm}^{-1}\right){ }^{3}$

\section{Conclusions}

We have synthesized and characterized new organonickel pincer complexes by the addition of 2-bromo-1,3-bis(3,5dimethylpyrazol-1-ylmethyl)benzene (1) and 2-bromo1,3-bis(indazol-2-ylmethyl)benzene (2) to [Ni(cod) ${ }_{2}$. The structure of $\mathbf{2}$ and of the complex [NiBr\{1,3-bis(indazol2-ylmethyl)phenyl- $N, C, N\}]$ (4) were confirmed by X-ray diffraction analysis. The nickel complexes are very stable and bromide abstraction only gives uncharacterized insoluble solids. When activated with MAO, complex 4 shows a moderate ethylene polymerization activity under mild conditions. The polymers produced had high molecular weight with narrow polydispersities, corresponding to single-site catalysts.

\section{Supplementary Information}

Crystallographic data for $\mathbf{2}$ and $\mathbf{4}$ have been deposited with the Cambridge Crystallographic Data Centre, CCDC numbers 783567 and 773707. Copies of this information may be obtained free of charge from CCDC, 12 Union Road, Cambridge, CB2 1EZ, UK (fax: 44-1223-336-033; e-mail: deposit@ccdc.cam.ac.uk or www: http://www. ccdc.cam.ac.uk). ${ }^{1} \mathrm{H}-\mathrm{NMR}$ and HMBC spectra of 2-bromo1,3-bis(indazol-2-ylmethyl)benzene and $[\mathrm{NiBr}\{1,3-$ bis(indazol-2-ylmethyl)phenyl- $N, C, N\}]$ are available free of charge at http://jbcs.sbq.org.br as PDF file.

\section{Acknowledgments}

We thank Fondo de Desarrollo Científico y Tecnológico (FONDECYT), Chile, for financial support under project numbers 1060597 and 1100286. J. H. acknowledges VRAI, Pontificia Universidad Católica de Chile and CONICYT for a doctoral fellowship.

\section{References}

1. Morales-Morales, D.; Jensen, C. M.; The Chemistry of Pincer Compounds. Elsevier: The Netherlands, 2007.

2. Serrano-Becerra, J. M.; Morales-Morales, D.; Curr. Org. Synth. 2009, 6, 169.
3. Morales-Morales, D.; Rev. Soc. Quim. Mex. 2004, 48, 338.

4. Singleton, J. T.; Tetrahedron 2003, 59,1837.

5. van der Boom, M. E.; Misltein, D.; Chem. Rev. 2003, 103, 1759.

6. Albrecht, M.; van Koten, G.; Angew. Chem., Int. Ed. 2001, 40, 3750 .

7. Kuroda, J.; Kiyofumi, I.; Hiroya, K.; Takayuki, D.; Eur. J. Org. Chem. 2009, 2251.

8. Rietveld, M. H. P.; Grove, D. M.; van Koten, G.; New J. Chem. 1997, 21, 752.

9. Fossey, J. S.; Richards, C. J.; J. Organomet. Chem. 2004, 689, 3056.

10. van de Kuil, L. A.; Luitjes, H.; Grove, D. M.; Zwikker, J. W.; van der Linden, J. G. M.; Roelofsen, A. M.; Jenneskens, L. W.; Drenth, W.; van Koten, G.; Organometallics 1994, 13, 468.

11. van Beek, J. A. M.; van Koten, G.; Ramp, M. J.; Coenjaarts, N. C.; Grove, D. M.; Goubits, K.; Zoutberg, M. C.; Stamp, C. H.; Smeets, W. J. J.; Spek, A. L.; Inorg. Chem. 1991, 30, 3059.

12. Grove, D. M.; van Koten, G.; Hubbels, H. J. C.; Zoet, R.; Organometallics 1984, 3, 1003.

13. Gossage, R. A.; van de Kuil, L. A.; van Koten, G.; Acc. Chem. Res. 1998, 31, 423.

14. van de Kuil, L. A.; Grove, D. M.; Gossage, R. A.; Zwikker, J. W.; Jenneskens, L. W.; Drenth, W.; van Koten, G.; Organometallics 1997, 16, 4985.

15. Zang, Y.; Song, G.; Ma, G.; Zhao, J.; Pan, C-L.; Li, X.; Organometallics 2009, 28, 3233.

16. Yoon, M. S.; Ryu, D.; Kim, J.; Ahn, K. H.; Organometallics 2006, 25, 2409.

17. Chiu, B. K-W.; Lam, M. H-W.; Lee, D. Y-K.; Wong, W-Y.; J. Organomet. Chem. 2004, 689, 2888.

18. Dijkstra, H. P.; Meijer, M. D.; Patel, J.; Kreiter, R.; van Klink, G. P. M.; Lutz, M.; Speck, A. L.; Canty, A.J.; van Koten, G.; Organometallics 2001, 20, 3159.

19. Canty, A. J.; Patel, J.; Skelton, B. W.; White, A. H.; J. Organomet. Chem. 2000, 607, 194.

20. Canty, A. J.; Patel, J.; Skelton, B. W.; White, A. H.; J. Organomet. Chem. 2000, 599, 195.

21. Hartshorn, M. C.; Steel, P. J.; Organometallics 1998, 17, 3487.

22. Canty, A. J.; Minchin, M. J.; Skelton, B. W.; White, A. H.; J. Chem. Soc., Dalton Trans. 1987, 1477.

23. Hurtado, J.; Ibañez, A.; Rojas, R.; Valderrama, M.; Inorg. Chem. Commun. 2010, 13, 1025.

24. Amijs, C. H. M.; van Klink, G. P. M.; van Koten, G.; Green Chem. 2003, 5, 470.

25. Sheldrick, G. M.; Acta Crystallogr. 1990, A46, 467; Sheldrick, G. M.; SHELXL-97, Program for Crystal Structure Refinement; Universität Göttingen: Germany, 1997.

26. Sheldrick, G. M.; SHELXTL V 5.1, Bruker AXS Inc.: Madison, WI, 1998.

27. Luo, G.; Chen, L.; Duwowchik, G.; J. Org. Chem. 2006, 71, 5392. 
28. Diez-Barra, E.; Guerra, J.; López-Solera, I.; Merino, S.; Rodríguez-López, J.; Sánchez-Verdú, P.; Tejeda, J.; Organometallics 2003, 22, 541.

29. Hurtado, J.; Portaluppi, M.; Quijada, R.; Rojas, R.; Valderrama, M.; J. Coord. Chem. 2009, 62, 2772.

30. Hurtado, J.; Mac-Leod Carey, D.; Muñoz-Castro, A.; ArratiaPérez, R.; Quijada, R.; Wu, G.; Rojas, R.; Valderrama, M.; J. Organomet. Chem. 2009, 694, 2636.

31. Pérez, M. A.; Quijada, R.; Ortega-Jiménez, F.; AlvarezToledano, C.; J. Mol. Catal. A: Chem. 2005, 226, 291
32. Boardman, B. M.; Valderrama, M.; Muñoz, F.; Wu, G.; Bazan, G. C.; Rojas, R.; Organometallics 2008, 27, 1671.

33. Azoulay, J. D.; Rojas, R.; Serrano, A. V.; Ohtaki, H.; Galland, G. B.; Wu, G.; Bazan, G. C.; Angew. Chem., Int. Ed. 2009, 48, 1089.

34. Dominguez, A. M.; Zárate, A.; Quijada, R.; López, T.; J. Mol. Catal. A: Chem. 2004, 207, 155.

Submitted: November 3, 2010

Published online: June 28, 2011 


\title{
Organonickel(II) Complexes with Anionic Tridentate 1,3-Bis(azolylmethyl)phenyl Ligands. Synthesis, Structural Characterization and Catalytic Behavior
}

\author{
John Hurtado, ${ }^{a}$ Andrés Ibañez, ${ }^{b}$ René Rojas, ${ }^{a}$ Mauricio Valderrama ${ }^{*, a}$ and Roland Fröhlich ${ }^{c}$ \\ ${ }^{a}$ Departamento de Química Inorgánica, Facultad de Química, \\ Pontificia Universidad Católica de Chile, Casilla 306, 6094411 Santiago, Chile
}

${ }^{b}$ Centro para la Investigación Interdisciplinaria Avanzada en Ciencia de los Materiales (CIMAT),

Santiago, Chile

${ }^{c}$ Organisch Chemisches Institut der Universität Münster, Corrensstrasse 40,

48149 Münster, Germany

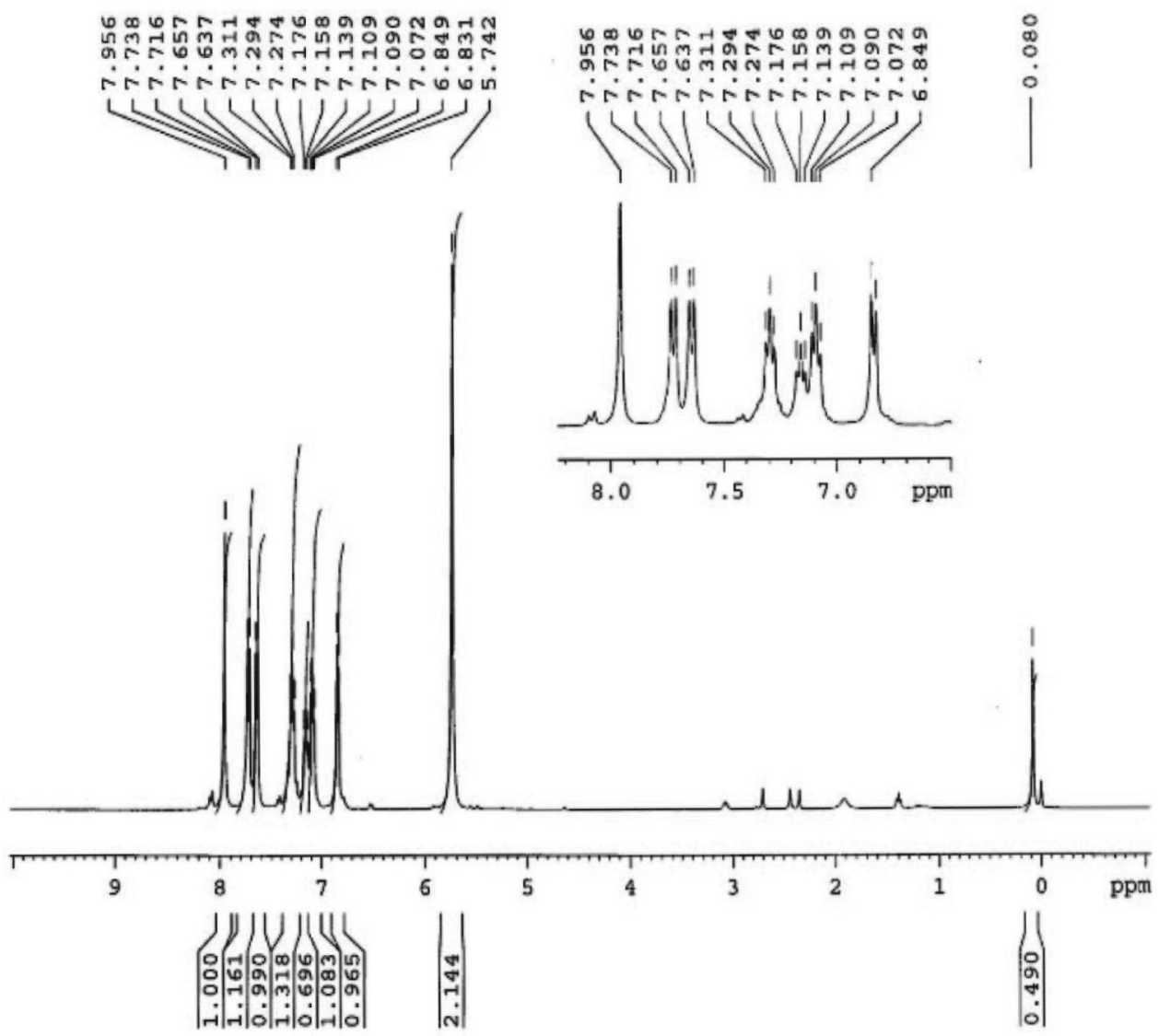

Figure S1. ${ }^{1} \mathrm{H}$ NMR $\left(\mathrm{CDCl}_{3}\right)$ spectrum of 2-bromo-1,3-bis(indazol-2-ylmethyl)benzene.

*e-mail: jmvalder@puc.cl 


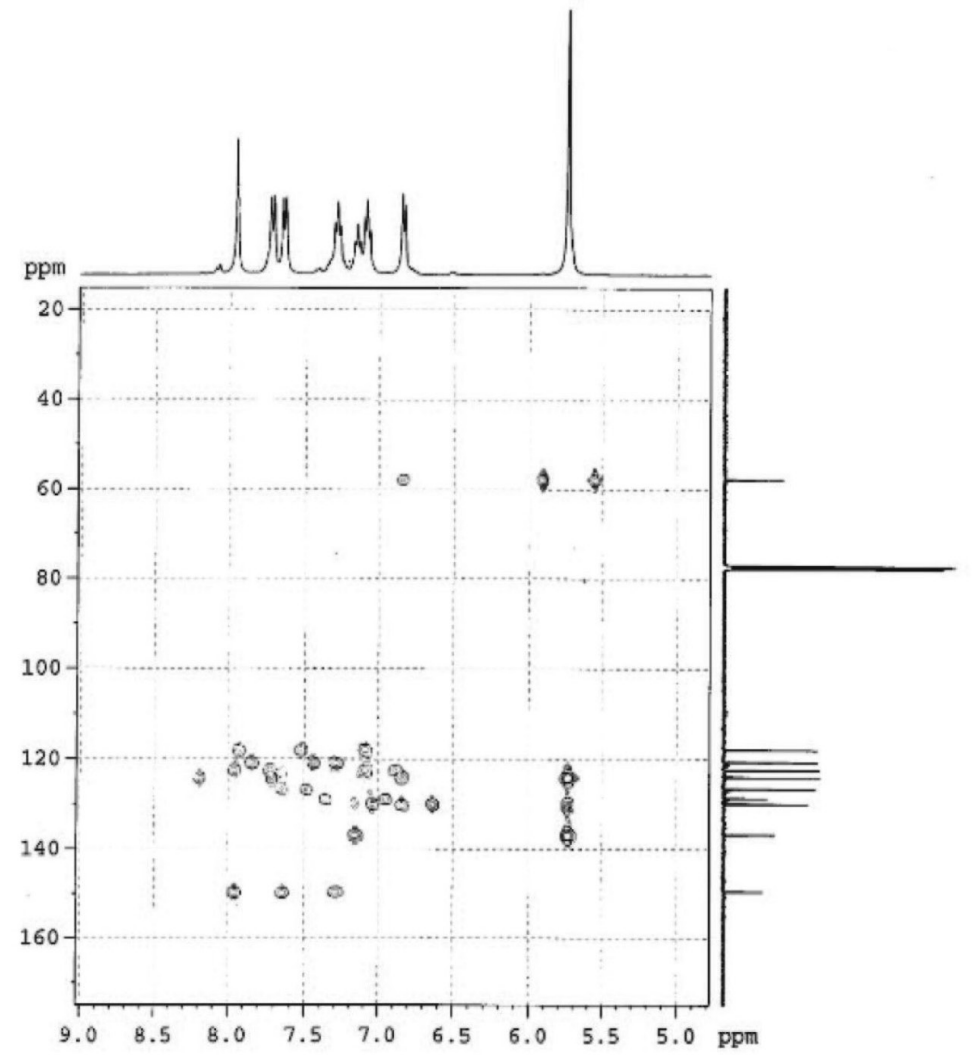

Figure S2. HMBC spectrum of 2-bromo-1,3-bis(indazol-2-ylmeyhyl)benzene.

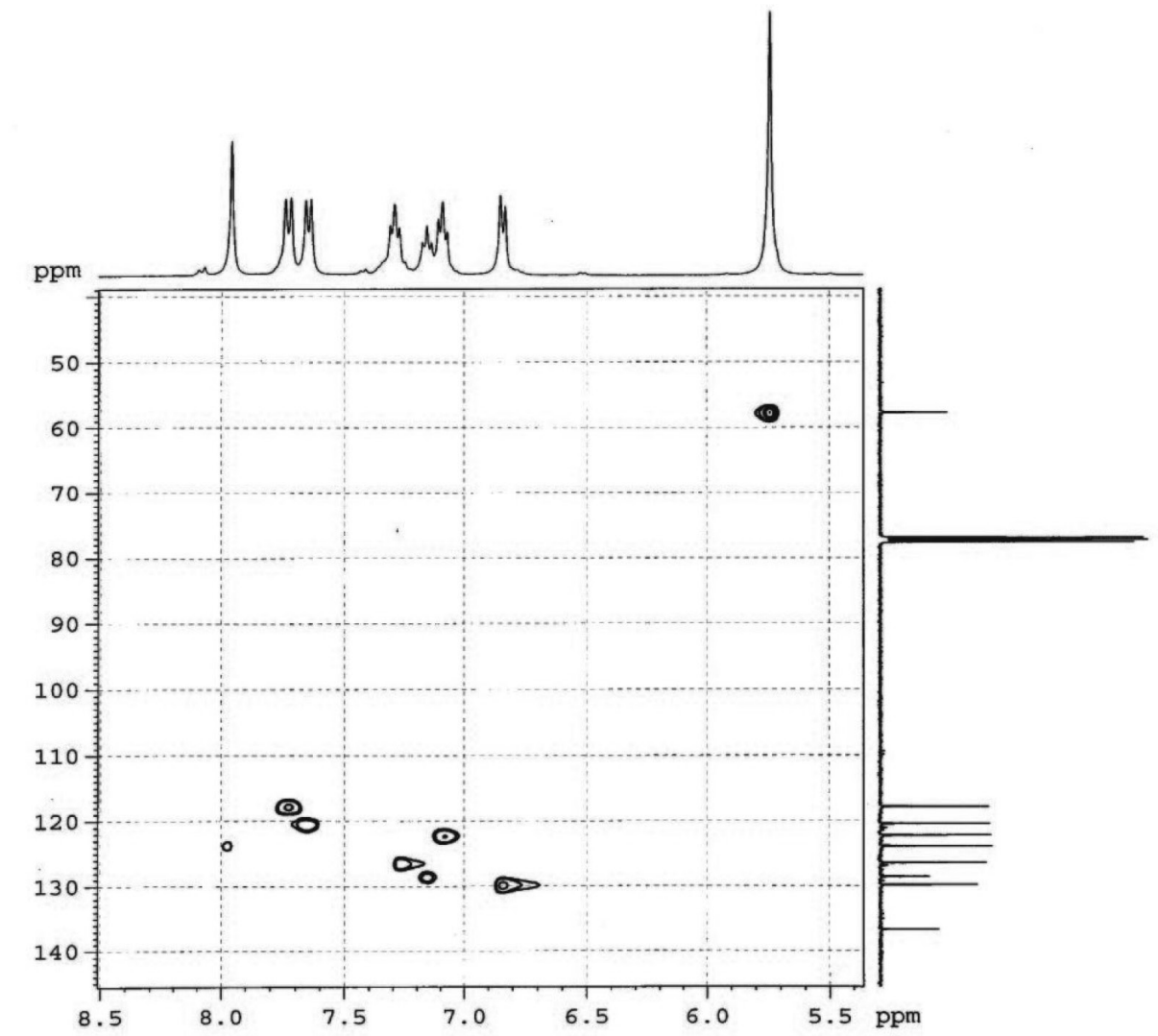

Figure S3. HSQC spectrum of 2-bromo-1,3-bis(indazol-2-ylmethyl)benzene. 

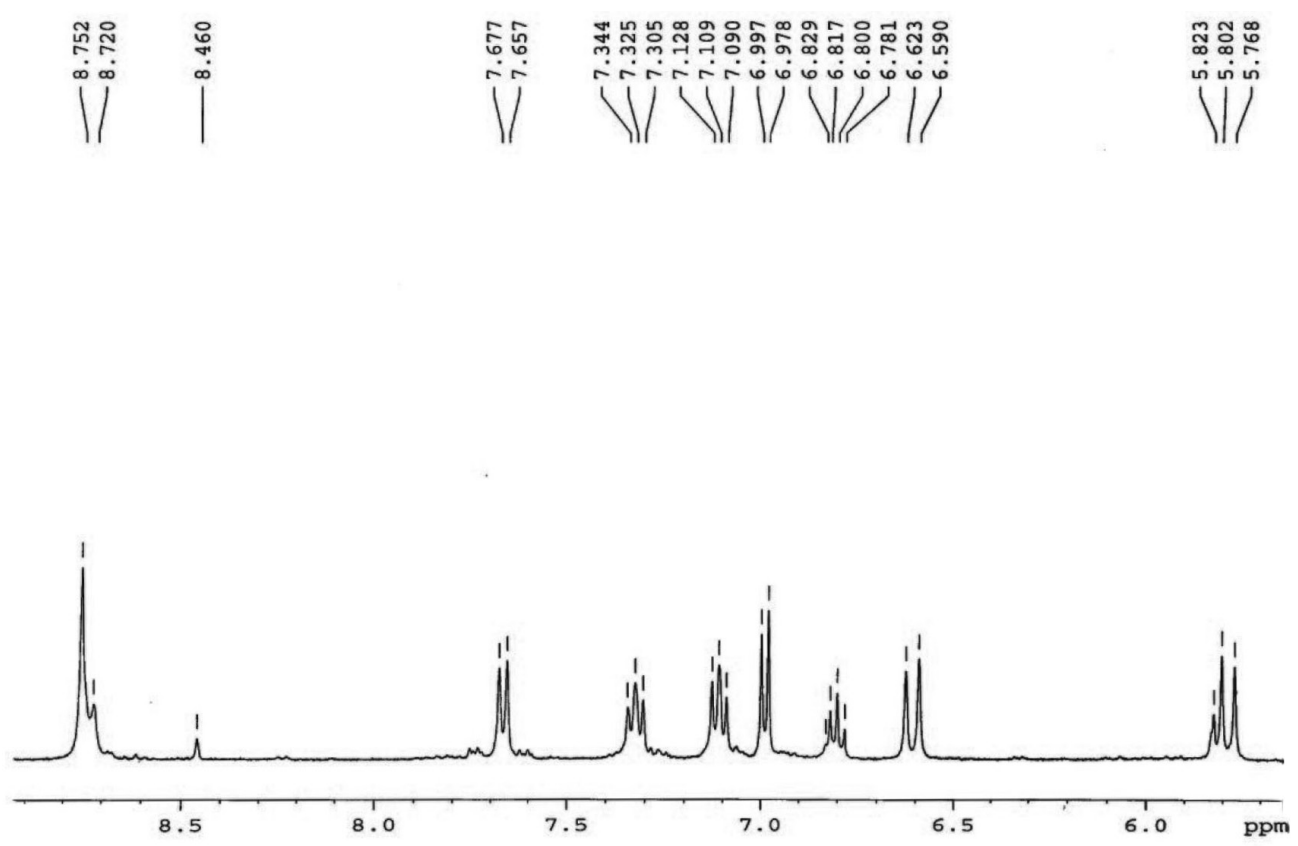

Figure S4. ${ }^{1} \mathrm{H}$ NMR (acetone) spectrum of $\mathrm{NiBr}\{1$,3-bis(indazol-2-ylmethyl)phenyl- $N, C, N\}$.

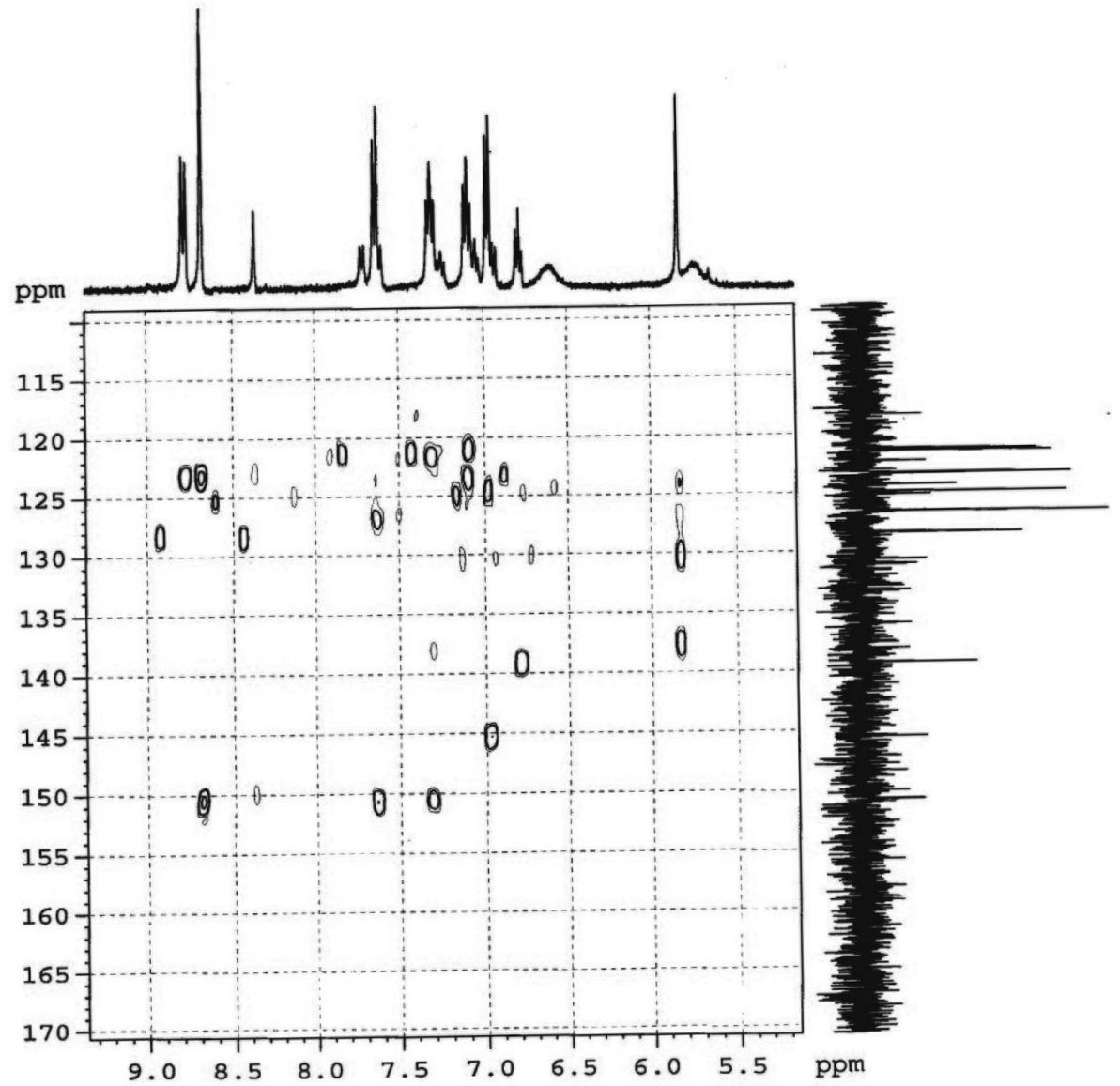

Figure S5. HMBC spectrum of $\mathrm{NiBr}\{1,3$-bis(indazol-2-ylmethyl)phenyl- $N, C, N\}$. 